\title{
Front Matter: Volume 7667
}

, "Front Matter: Volume 7667," Proc. SPIE 7667, Biometric Technology for Human Identification VII, 766701 (14 April 2010); doi: 10.1117/12.863404

SPIE Event: SPIE Defense, Security, and Sensing, 2010, Orlando, Florida, United SPIE. States 


\section{PROCEEDINGS OF SPIE}

\section{Biometric Technology for Human Identification VII}

B. V. K. Vijaya Kumar

Salil Prabhakar

Arun A. Ross

Editors

5-6 April 2010

Orlando, Florida, United States

Sponsored and Published by

SPIE

Volume 7667 
The papers included in this volume were part of the technical conference cited on the cover and title page. Papers were selected and subject to review by the editors and conference program committee. Some conference presentations may not be available for publication. The papers published in these proceedings reflect the work and thoughts of the authors and are published herein as submitted. The publisher is not responsible for the validity of the information or for any outcomes resulting from reliance thereon.

Please use the following format to cite material from this book:

Author(s), "Title of Paper," in Biometric Technology for Human Identification VII, edited by B. V. K. Vijaya Kumar, Salil Prabhakar, Arun A. Ross, Proceedings of SPIE Vol. 7667 (SPIE, Bellingham, WA, 2010) Article CID Number.

ISSN 0277-786X

ISBN 9780819481313

Published by

SPIE

P.O. Box 10, Bellingham, Washington 98227-0010 USA

Telephone +1 3606763290 (Pacific Time) · Fax +1 3606471445

SPIE.org

Copyright (C) 2010, Society of Photo-Optical Instrumentation Engineers

Copying of material in this book for internal or personal use, or for the internal or personal use of specific clients, beyond the fair use provisions granted by the U.S. Copyright Law is authorized by SPIE subject to payment of copying fees. The Transactional Reporting Service base fee for this volume is $\$ 18.00$ per article (or portion thereof), which should be paid directly to the Copyright Clearance Center (CCC), 222 Rosewood Drive, Danvers, MA 01923. Payment may also be made electronically through CCC Online at copyright.com. Other copying for republication, resale, advertising or promotion, or any form of systematic or multiple reproduction of any material in this book is prohibited except with permission in writing from the publisher. The CCC fee code is $0277-786 \mathrm{X} / 10 / \$ 18.00$.

Printed in the United States of America.

Publication of record for individual papers is online in the SPIE Digital Library.

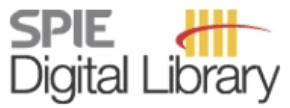

SPIEDigitalLibrary.org

Paper Numbering: Proceedings of SPIE follow an e-First publication model, with papers published first online and then in print and on CD-ROM. Papers are published as they are submitted and meet publication criteria. A unique, consistent, permanent citation identifier (CID) number is assigned to each article at the time of the first publication. Utilization of CIDs allows articles to be fully citable as soon they are published online, and connects the same identifier to all online, print, and electronic versions of the publication. SPIE uses a six-digit CID article numbering system in which:

- The first four digits correspond to the SPIE volume number.

- The last two digits indicate publication order within the volume using a Base 36 numbering system employing both numerals and letters. These two-number sets start with 00, 01, 02, 03, 04, $05,06,07,08,09,0 A, 0 B \ldots 0 Z$, followed by 10-1Z, 20-2Z, etc.

The CID number appears on each page of the manuscript. The complete citation is used on the first page, and an abbreviated version on subsequent pages. Numbers in the index correspond to the last two digits of the six-digit CID number. 


\section{Contents}

vii Conference Committee
ix Introduction

\section{SESSION 1 FACE ANALYSIS}

766702 Sketch-to-photo matching: a feature-based approach [7667-01]

B. Klare, Michigan State Univ. (United States); A. K. Jain, Michigan State Univ. (United States) and Korea Univ. (Korea, Republic of)

766703 A novel thermal face recognition approach using face pattern words [7667-02]

Y. Zheng, Alcorn State Univ. (United States)

766704 Superquadric representation of 3D faces: Toward reducing time complexity of recognition [7667-03]

M. Mudigonda, G. C. Stockman, Michigan State Univ. (United States)

766705 Face recognition for uncontrolled environments [7667-04]

C. Podilchuk, W. Hulbert, R. Flachsbart, L. Barinov, DSCI (United States)

766706 Face recognition motivated by human approach (Invited Paper) [7667-05]

B. Kamgar-Parsi, U.S. Naval Research Lab. (United States); W. E. Lawson, U.S. Naval Research Lab. (United States) and George Mason Univ. (United States); B. Kamgar-Parsi, Office of Naval Research (United States)

\section{SESSION 2 FINGERPRINT ANALYSIS}

766707 On latent fingerprint enhancement [7667-06]

S. Yoon, J. Feng, Michigan State Univ. (United States); A. K. Jain, Michigan State Univ. (United States) and Korea Univ. (Korea, Republic of)

766708 Mobile, contactless, single-shot, fingerprint capture system [7667-07]

G. Abramovich, K. Harding, S. Manickam, J. Czechowski, V. Paruchuru, R. Tait, C. Nafis, GE Global Research (United States); A. Vemury, U.S. Dept. of Homeland Security (United States)

766709 Tools for quality control of fingerprint databases [7667-08]

B. S. Swann, Federal Bureau of Investigation (United States); J. M. Libert, National Institute of Science and Technology (United States); M. A. Lepley, MITRE Corp. (United States)

\section{SESSION 3 LARGE-SCALE SYSTEMS, SECURITY, AND PRIVACY}

7667 OB Visual cryptography for face privacy [7667-10]

A. Ross, A. A. Othman, West Virginia Univ. (United States) 
7667 OC Cryptographically secure biometrics [7667-11]

A. Stoianov, Office of Information and Privacy Commissioner of Ontario (Canada)

7667 OD Analytical template protection performance and maximum key size given a Gaussianmodeled biometric source [7667-12]

E. J. C. Kelkboom, J. Breebaart, I. Buhan, Philips Research (Netherlands); R. N. J. Veldhuis, Univ. Twente (Netherlands)

7667 OE A hierarchical fingerprint alignment method and its application to fuzzy vault [7667-13] P. Li, X. Yang, Y. Zang, K. Cao, Institute of Automation (China); J. Tian, Institute of Automation (China) and Xidian Univ. (China)

\section{SESSION 4 STATISTICAL MODELING AND EVALUATION}

7667 OF A central-limit theorem for a single false match rate [7667-14]

Z. Dietz, Hamilton College (United States); M. E. Schuckers, St. Lawrence Univ. (United States)

7667 OG Multi-order analysis framework for comprehensive biometric performance evaluation [7667-15]

D. O. Gorodnichy, Canada Border Services Agency (Canada)

$7667 \mathrm{OH} \quad$ A definitional framework for the human/biometric sensor interaction model [7667-16] S. J. Elliott, E. P. Kukula, Purdue Univ. (United States)

7667 Ol Significance test in operational ROC analysis [7667-33]

J. C. Wu, A. F. Martin, R. N. Kacker, C. R. Hagwood, National Institute of Standards and Technology (United States)

\section{SESSION $5 \quad$ IRIS AND EMERGING BIOMETRICS}

7667 0J Aspects of iris image and iris match pair quality (Invited Paper) [7667-17] P. J. Flynn, K. W. Bowyer, Univ. of Notre Dame (United States)

7667 OK Fast and efficient iris image enhancement using logarithmic image processing [7667-18] N. Sazonova, S. Schuckers, Clarkson Univ. (United States)

7667 OL Continuous user authentication using temporal information [7667-19]

K. Niinuma, Fujitsu Labs. (Japan); A. K. Jain, Michigan State Univ. (United States)

7667 OM Robust human identification using ECG: eigenpulse revisited [7667-20] D. Jang, Scitor Corp. (United States); S. Wendelken, J. M. Irvine, The Charles Stark Draper Lab., Inc. (United States)

7667 ON New biometric modalities using internal physical characteristics [7667-21] J. (Brooks) Mortenson, General Resonance, LLC (United States) 
7667 OP Automated person categorization for video surveillance using soft biometrics [7667-23] M. Demirkus, McGill Univ. (Canada) and intuVision, Inc. (United States); K. Garg, S. Guler, intuVision, Inc. (United States)

7667 OQ Gait curves for human recognition, backpack detection, and silhouetfe correction in a nighttime environment [7667-24]

B. DeCann, A. Ross, West Virginia Univ. (United States)

7667 OR An automated process for deceit detection [7667-25]

I. Nwogu, M. Frank, V. Govindaraju, Univ. at Buffalo (United States)

7667 OS Accurate pose estimation for forensic identification [7667-26]

G. Merckx, J. Hermans, D. Vandermeulen, Katholieke Univ. Leuven (Belgium)

SESSION 7 MULTIBIOMETRICS

7667 OT A study of multibiometric traits of identical twins [7667-27]

Z. Sun, Institute of Automation (China); A. A. Paulino, J. Feng, Michigan State Univ. (United States); Z. Chai, T. Tan, Institute of Automation (China); A. K. Jain, Michigan State Univ. (United States) and Korea Univ. (Korea, Republic of)

7667 oU A multibiometric face recognition fusion framework with template protection [7667-28]

S. Chindaro, F. Deravi, Z. Zhou, M. W. R. Ng, Univ. of Kent (United Kingdom); M. Castro Neves, X. Zhou, Fraunhofer Institute for Computer Graphics Research (Germany); E. Kelkboom, Philips Research (Netherlands)

7667 OV When data goes missing: methods for missing score imputation in biometric fusion [7667-29] Y. Ding, A. Ross, West Virginia Univ. (United States)

SESSION 8 FACE AND EAR ANALYSIS

7667 OW Batch mode active learning for biometric recognition [7667-30]

S. Chakraborty, V. Balasubramanian, S. Panchanathan, Arizona State Univ. (United States)

7667 OX Assessment of H.264 video compression on automated face recognition performance in surveillance and mobile video scenarios [7667-31]

B. Klare, Michigan State Univ. (United States); M. Burge, Noblis, Inc. (United States)

7667 OY Ear recognition under partial occlusion based on neighborhood preserving embedding [7667-32]

L. Yuan, Z. Wang, Z. Mu, Univ. of Science and Technology Beijing (China)

Author Index 
Downloaded From: https://www.spiedigitallibrary.org/conference-proceedings-of-spie on 25 Apr 2023

Terms of Use: https://www.spiedigitallibrary.org/terms-of-use 


\title{
Conference Committee
}

\author{
Symposium Chair \\ Michael T. Eismann, Air Force Research Laboratory (United States) \\ Symposium Cochair \\ William Jeffrey, HRL Laboratories, LLC (United States) \\ Conference Chairs
}

B. V. K. Vijaya Kumar, Carnegie Mellon University (United States)

Salil Prabhakar, DigitalPersona, Inc. (United States)

Arun A. Ross, West Virginia University (United States)

Program Committee

George Bebis, University of Nevada, Reno (United States)

Patrizio Campisi, Università degli Studi di Roma Tre (Italy)

Yi Chen, DigitalPersona, Inc. (United States)

Dirk J. L. Colbry, Michigan State University (United States)

Julian Fierrez, Universidad Autónoma de Madrid (Spain)

Patrick J. Flynn, University of Notre Dame (United States)

Michael D. Garris, National Institute of Standards and Technology

(United States)

Venu Govindaraju, University at Buffalo (United States)

John M. Irvine, The Charles Stark Draper Laboratory, Inc. (United States)

Anil K. Jain, Michigan State University (United States)

Sabah A. Jassim, University of Buckingham (United Kingdom)

loannis A. Kakadiaris, University of Houston (United States)

Josef Kittler, University of Surrey (United Kingdom)

Ajay Kumar, The Hong Kong Polytechnic University (Hong Kong, China)

Stan Z. Li, Chinese Academy of Sciences (China)

David Maltoni, Università degli Studi di Bologna (Italy)

Brian Martin, L-1 Identity Solutions, Inc. (United States)

Karthik Nandakumar, A*STAR Institute for Infocomm Research (United

States)

Lisa Ann Osadciw, Syracuse University (United States)

Konstantinos N. Plataniotis, University of Toronto (Canada)

Amit Roy-Chowdhury, University of California, Riverside (United States)

Sudeep Sarkar, University of South Florida (United States)

Marios Savvides, Carnegie Mellon University (United States)

Michael E. Schuckers, St. Lawrence University (United States)

Alex Stoianov, Information and Privacy Commission (Canada)

Kar-Ann Toh, Yonsei University (Korea, Republic of) 
Berrin Yanikoglu, Sabanci University (Turkey)

Session Chairs

1 Face Analysis

B. V. K. Vijaya Kumar, Carnegie Mellon University (United States)

2 Fingerprint Analysis

Salil Prabhakar, DigitalPersona, Inc. (United States)

3 Large-Scale Systems, Security, and Privacy

B. V. K. Vijaya Kumar, Carnegie Mellon University (United States)

$4 \quad$ Statistical Modeling and Evaluation

Michael E. Schuckers, St. Lawrence University (United States)

$5 \quad$ Iris and Emerging Biometrics

Stephanie C. Schuckers, Clarkson University (United States)

6 Soft Biometrics and Forensics

Salil Prabhakar, DigitalPersona, Inc. (United States)

$7 \quad$ Multibiometrics

Venu Govindaraju, University at Buffalo (United States)

$8 \quad$ Face and Ear Analysis

Arun A. Ross, West Virginia University (United States) 


\section{Introduction}

Biometrics is the science of establishing human identity based on the physical (e.g., face, fingerprint, iris) and behavioral (e.g., signature, gait) traits of an individual. Reliable identification of humans in an automated manner is a very important topic in a number of law enforcement (e.g., criminal investigation), government (e.g., border control), and commercial (e.g., logical and physical access control) applications. With increased emphasis on security, there is a growing and urgent need to automatically identify humans both locally and remotely on a routine basis.

The goal of the $7^{\text {th }}$ edition of the SPIE Biometric Technology for Human Identification conference is to provide a scientific forum for researchers, engineers, system architects and designers to report recent advances in this important area of human identification using biometrics. We received a total of 50 paper submissions this year. Based on the comments and recommendations of the Program Committee, 30 papers were selected for presentation. These papers span a variety of topics in biometrics including analysis of face, fingerprint, ear and iris; template security and privacy; statistical modeling and evaluation; emerging and novel biometrics such as ECG and "boneprints"; soft biometrics and nighttime gait recognition; and multibiometric fusion. International researchers from academia, industry, and government will present these papers over 8 sessions April 5-6 2010.

The event will also feature three invited speakers: Dr. Behrooz Kamgar-Parsi from the U.S. Naval Research Lab, Dr. Jean-Christophe Fondeur from Sagem Défense Sécurité, France and Prof. Patrick J. Flynn from the University of Notre Dame in the U.S. Their presentations will cover the topics of face recognition, large-scale biometrics, and iris recognition, respectively.

We are very grateful to the program committee members for their excellent support and the authors for the high-quality papers. We are thankful to the SPIE staff for their remarkable assistance in organizing the conference. We sincerely hope you enjoy reading the compilation of technical papers in this publication.

\section{B. V. K. Vijaya Kumar Salil Prabhakar Arun A. Ross}


Downloaded From: https://www.spiedigitallibrary.org/conference-proceedings-of-spie on 25 Apr 2023

Terms of Use: https://www.spiedigitallibrary.org/terms-of-use 